Daniel Elmiger*

\title{
Equal status, but unequal perceptions: language conflict in the bilingual city of Biel/Bienne
}

DOI 10.1515/ijsl-2015-0013

\begin{abstract}
The city of Biel/Bienne is often cited as a model of a non-conflicting cohabitation between two language groups with a similar status: German (i.e. in a diglossic situation: Standard German and Swiss German dialects) and French both benefit from explicit political promotion and legal protection. In a qualitative study conducted in the city of Biel/Bienne, most of the 40 interviewees talking about their lives in this bilingual city confirm this consensual view of linguistic cohabitation. However, the apparent balance between both communities is challenged on different levels, including the relationship between language communities according to their respective minority and majority status, the status and the visibility of both languages in the public sphere, the conflicting loyalties of bilingual citizens, the use or avoidance of a language in certain contexts or the choice of a common language in (potentially) bilingual interactions. The results of the analysis reveal divergent - and potentially conflicting - perceptions regarding urban bilingualism: although most of the interviewees appreciate the linguistic cohabitation in Biel/Bienne, many of them refer to various zones of language conflict which they suffer from or which they allot to the other speech community.
\end{abstract}

Keywords: language conflict, bilingualism, Biel/Bienne, German, French

\section{Introduction}

In what has become an increasingly popular research field, many researchers using different research paradigms - have been able to identify and describe language-related conflicts in a large variety of contexts where languages come into contact with each other. The idea that the contact of languages - or varieties of them - is associated with conflicting issues has been explored by a number of researchers. Examples include Calvet's La guerre des langues (Calvet 1987), Nelde's "Language contact means language conflict" (Nelde 1987), or, more recently,

*Corresponding author: Daniel Elmiger, University of Geneva, Geneva, Switzerland, E-mail: daniel.elmiger@unige.ch 
Hitchings' The language wars in which the author states that "wherever more than one language is used, conflict of some kind is inevitable" (Hitchings 2011: 139). ${ }^{1}$

In general, language conflicts do not arise from the languages themselves, but from the social, political, economic, cultural or religious issues in which languages become symbols for different groups of people and their values, aspirations or claims (cf. Nelde 1998; Darquennes et al. 2004).

The study of language conflicts often deals with language policy issues at the macro-level of society in contexts where two (or more) language communities are in contact. In such cases language conflict revolves around topics such as the following:

- The status of minority languages in public administration, schooling etc.: e.g. the status of minority languages in France or the status of Catalan in Catalonia, Spain (cf. Boix Fuster and Farràs 2013; Darquennes 2013).

- The use (or avoidance) of certain languages as official varieties in politics, science and other fields: e.g. the supremacy of English in various contexts and the movements of defence it is causing (cf. Ammon 2006).

- Language use and language policies in post-colonial or post-hegemonic contexts (e.g. Post-soviet contexts, cf. Pavlenko 2009) or in multilingual settings like the Arab-speaking regions (cf. Rouchdy 2003) and the European Union (cf. Ammon 2006; Darquennes 2010).

- The institutionalisation and legitimisation of immigrant languages (cf. Extra and Yağmur 2004).

- The cohabitation of linguistically and ethnically diversified (urban) communities where multiple (linguistic) identities challenge traditional group memberships (cf. Mac Giolla Chríost 2003; Nelde 2006) and diversify the public linguistic landscape (cf. Shohamy and Gorter 2009).

- The choice of legitimised standard varieties such as the controversy between Bokmål and Nynorsk in Norwegian (cf. Trudgill 1997).

None of these points appear to be particularly relevant in Biel/Bienne, where the conditions for equal treatment and the non-conflicting cohabitation of the two official languages at the macro-level of society are rather promising. In the specific context of Biel/Bienne, where the social, economic and political issues related to language contact are less heavily disputed (or at least less visible) than elsewhere, we take a closer look at language conflict at the personal/individual, micro-level of society. Relying on Haarmann (1990: 2-3), according to whom “actual language

1 Cf. also Oksaar (1984), who combined the notions of linguistic acquisition, contact and conflict. 
conflict exists in the person's consciousness" "2 we focus on the linguistic tensions that individuals face when dealing with implicit and explicit rules of communication in a bi-/multilingual setting (cf. Section 5). Before doing that, however, the article first provides a presentation of the language setting in Switzerland, in general, and the city of Biel/Bienne, in particular (cf. Section 2). It gives an overview of the research project bil.bienne from which the data for this article was obtained (cf. Section 3) and it focuses on the reasons for the - in general peaceful cohabitation of languages communities in Biel/Bienne (Section 4).

\section{Language policy and multilingualism in Switzerland: too much consensus?}

Switzerland is often considered as a country in which an essentially consensual cohabitation of language communities can be observed. The same is said about a number of bilingual regions or towns, such as Biel/Bienne. There, French/ German bilingualism has an official status, while other languages may have a considerable presence without being officially recognised within the political and legal setting. The following sections summarises the legal situation regarding language policy in Switzerland and Biel/Bienne.

\subsection{The legal situation in Switzerland and in Biel/Bienne}

Switzerland is a federal state with four national languages (German, French, Italian and since 1938 Romansh), only three of which are official languages on the Federal level (Romansh has a so-called semi-official status, being an official language only for Romansh-speaking citizens). ${ }^{3}$ Language policy is addressed at different levels. The following general principles contribute to an overall nonconflicting linguistic cohabitation in the whole of Switzerland:

- The subsidiarity principle: political action is taken at the lowest or least centralised level, i.e., in language matters, in general by the Cantons and not the Federal state.

- The language freedom principle: the Federal Constitution guarantees the freedom to use any language (art. 18), i.e. in the private sphere (as

2 This view is of course favoured - and partially determined - by the data that has been collected in the research project bil.bienne (see Section 3.1).

3 See the Federal Constitution of the Swiss Confederation (http://www.admin.ch/ch/e/rs/c101. html), Articles 4 and 70 (accessed 7 July 2015). 
opposed to the official domains of language use, where an official language may be imposed).

- The principle of territoriality: the Cantons have the right to decide on their official languages. They are requested to "respect the traditional territorial distribution of languages and take account of indigenous linguistic minorities" in order to "preserve harmony between linguistic communities" (Federal Constitution, Article 70.2). Historically, this principle has proved to be quite effective in keeping the language territories stable.

At the cantonal level (i.e. the level of the administrative districts), each canton decides which language(s) it considers as official language(s) on its territory. Twenty two cantons are officially monolingual (seventeen German, four French, one Italian), three cantons are bilingual (French/German) and one canton is trilingual (German/Italian/Romansh). The canton of Berne, in which the city of Biel/Bienne is located, is one of three bilingual cantons. The canton's majority population is German-speaking. The French-speakers represent about $8 \%$ of the total population and clearly build a minority within the canton of Bern. ${ }^{4}$

Biel/Bienne (see Figure 1) is an important city in the canton of Berne, located on the Germanic-Romance language border. Its bilingualism is not only anchored legally. ${ }^{5}$ It is also visible in the city's official name. In everyday use, Biel is used in German and Bienne in French. In this text, we will mainly focus on the relationship between these two official languages, even though

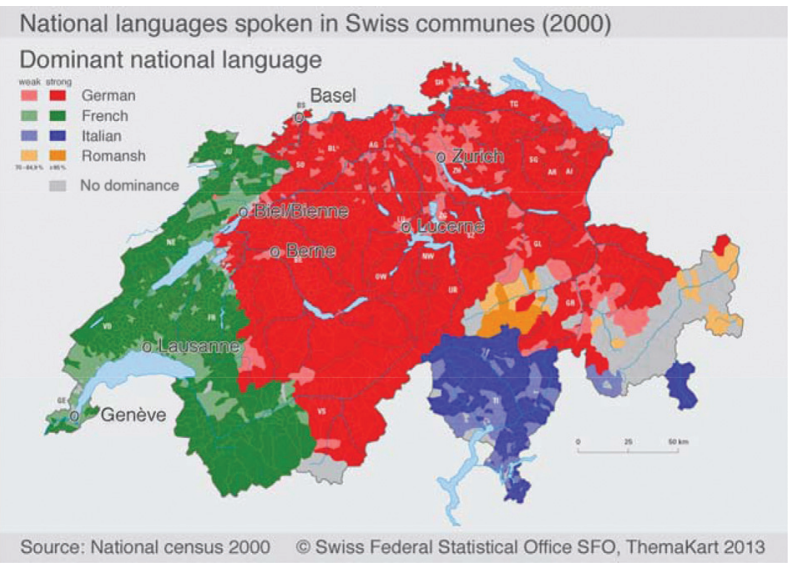

Figure 1: National languages spoken in Swiss communes (@SFO, ThemaKart 2013).

4 See Werlen (2000) for the general linguistic context in the canton Berne.

5 The status of the bilingual district of Biel/Bienne, to which the city of Biel/Bienne belongs, is defined in a cantonal law (Law on the particular status; German: Sonderstatutsgesetz; French: Loi sur le statut particulier): http://www.sta.be.ch/belex/d/1/102_1.html (accessed 7 July 2015). 
they only represent a part of the individual and social multilingualism that exists in a modern city like Biel/Bienne where dozens of other languages are spoken. Therefore, the reader must keep in mind that we cannot take into account all facets of language-related conflicts in the Biel/Bienne context.

In comparison to other bilingual zones in Switzerland, Biel's bilingualism in its actual proportion is a relatively new phenomenon, which is based essentially on massive immigration of (mostly French-speaking) workers starting from the second half of the 19th century (cf. Conrad and Elmiger 2010: 9-13).

Today, about 50,000 people live in Biel/Bienne. Overall, German has a stronger presence than French, but the French-speaking group can be considered a substantial minority. German is the preferred official language of about $60 \%$ of the population. French is the preferred official language of about $40 \%$ (Stadt Biel/ Ville de Bienne 2012: 5). Of course, the obligatory selection of one official language (it is not possible, e.g., for bilingual persons, to choose both languages) only roughly reflects the languages spoken by the people living in Biel/Bienne. In 2000, the National Census only asked for one main spoken language. For Biel/ Bienne and the whole country, the results are shown in Table 1.

Table 1: The main spoken language of the inhabitants of Biel/Bienne and Switzerland.

\begin{tabular}{lrr}
\hline Language & Biel/Bienne & Switzerland \\
\hline German & $55.4 \%$ & $63.7 \%$ \\
French & $28.1 \%$ & $20.4 \%$ \\
Italian & $6.0 \%$ & $6.5 \%$ \\
Spanish & $2.2 \%$ & $1.1 \%$ \\
Albanian & $1.4 \%$ & $1.3 \%$ \\
Portuguese & $1.1 \%$ & $1.2 \%$ \\
Languages of former & $1.1 \%$ & $1.4 \%$ \\
$\quad$ Yugoslavia & & \\
Turkish & $0.9 \%$ & $0.6 \%$ \\
English & $0.5 \%$ & $1.0 \%$ \\
Romansh & $0.1 \%$ & $0.5 \%$ \\
Others & $3.2 \%$ & $2.3 \%$ \\
\hline
\end{tabular}

Source: cf. Lüdi and Werlen (2005: 11) and Stadt Biel/Ville de Bienne (2012: 5).

Given the fact that the Swiss language territories are generally rather homogeneous (see Figure 1) and tend towards even more uniformity (Lüdi and Werlen 2005: 14), it is interesting to see how closely the language mix in Biel/Bienne resembles the one that can be observed in the whole country. 
However, the numbers presented above do not take into account individual bilingualism or multilingualism, both of which are quite frequent in Biel/Bienne. According to the municipal statistical service, $36.9 \%$ of the population is considered monolingual, 32.9\% bilingual and 20.3\% trilingual or multilingual (Stadt Biel/Ville de Bienne 2012: 6).

Data about the subjective self-evaluation of language proficiency can also be found in the "Biel/Bienne bilingualism barometer" (Longchamp et al. 2008a, 2008b). According to the barometer data, 94\% of the inhabitants speak French at least "sufficiently" (Longchamp et al. 2008a: 23; Longchamp et al. 2008b: 28); 89\% understand Standard German at least "sufficiently" (Longchamp et al. 2008a: 24; Longchamp et al. 2008b: 29), and 91\% understand the Swiss German dialect, i.e. the spoken variety in everyday use (see Section 5.2), at least "sufficiently” (Longchamp et al. 2008a: 25; Longchamp et al. 2008b: 29: 31).

\subsection{Double language policy in Biel/Bienne}

The city of Biel/Bienne promotes itself as a bilingual city. Its official web page (www.biel.ch or www.bienne.ch) says: Welcome to Biel/Bienne - the biggest bilingual city in Switzerland and the world capital for watchmaking. ${ }^{6}$ Biel's official bilingualism is used as an asset to attract communication-related economic activities. $^{7}$ Especially since the second half of the 20th century, the city has made a serious effort toward the sustained promotion of bilingualism through the continuous extension of its public services (such as schooling and bilingual public institutions) and the Forum of Bilingualism. ${ }^{8}$ Established as a public foundation in 1996, the Forum promotes bi/multilingualism through various events, scientific and economic projects (e.g. via a "label of bilingualism" for companies or institutions that encourage the use of more than one language for both internal and external communication).

In spite of the widespread presence of bilingualism in the population, the general language policy in Biel/Bienne in actual fact pulls in two very different directions - this is something of a contradiction at the heart of the policy. On the

6 German: Willkommen in Biel/Bienne - grösste zweisprachige Stadt der Schweiz und Uhrenweltmetropole; French: Bienvenue à Biel/Bienne - la plus grande ville bilingue de Suisse et capitale mondiale de l'horlogerie.

7 Flubacher and Duchêne (2012) point out, however, that in a context where the language proficiency of the population is used as an argument to attract new enterprises, individual bi- $/$ multilingualism is taken for granted and not sufficiently rewarded.

8 German: Forum für die Zweisprachigkeit; French: Forum du bilinguisme; see http://www. bilinguisme.ch/ (accessed 7 July 2015). 
one hand, the city actively promotes individual as well as social bilingualism (which itself is based on as much personal bilingualism as possible). On the other hand, it must also guarantee that monolingual individuals have the right to live with one language - and have access to all essential services in their preferred official language (cf. Elmiger 2005). Hence, the city has to promote both languages individually (e.g. monolingual services or cultural activities in both languages) as well as collectively (e.g. bilingual events or exchange programmes), which can give rise to divergent expectations that are difficult to meet and may give rise to various kinds of frustration.

\section{Research on bilingualism in Biel/Bienne}

\subsection{About the project bil.bienne}

Whereas a considerable amount of data exists about the languages spoken by people living in Biel/Bienne, less information is available about the actual use of languages, be it in private or official contexts. Previous linguistic research has revealed certain patterns of use (e.g. Kolde 1981; Müller 1987; cf. Conrad and Elmiger 2010, for an overview). At the time when the project bil.bienne bilinguisme à bienne - kommunikation in biel was initiated, relatively little was known about language choice in everyday situations.

The main goal of the project was to gain better insight into language use and language choice in monolingual as well as bilingual people's networks (at home, with friends, among neighbours, at work, etc.). Therefore, two series of recorded interviews were planned and carried out. The fieldwork for the project was conducted between 2000 and 2004. The results have been published in Conrad and Elmiger (2005, 2010) and Elmiger and Conrad (2006).

In the first module, 40 semi-structured interviews were conducted with citizens living in Biel/Bienne with diverse social and linguistic backgrounds (length: 45-100 min.; see Conrad and Elmiger 2010: 18-19, for more details on the methodology). During the semi-structured interviews, a series of topics were addressed: the perception of Biel/Bienne as a linguistic space, the interviewees' language biography and their experiences within a bilingual setting, the rules of language use and language choice in their social networks, etc. ${ }^{9}$

9 The excerpts used in this text are taken from the first project module, i.e. the recorded interviews. See Appendix for transcription conventions. 
In the second module, language choice in interactions between strangers was observed: the project collaborators made 70 short recordings (length: about 2-8 minutes) with people in public places (city streets, shops, public administration, etc.), engaging in everyday interactions such as asking someone the way, buying a product or requesting an information. Each person that addressed was notified about the recording and its purpose afterwards, so that the spontaneous language choice could be observed independently from potential personal or ideological preconceptions. If the recorded person allowed the team to keep the recording, a series of questions about his or her language repertoire and language use followed the initial interaction. ${ }^{10}$

\subsection{Language use and language choice}

One of the main goals of the bil.bienne-Project was to gain better insight into language use and language choice in everyday interactions. As was to be expected, no simple rule governs language choice in a city where two main languages coexist alongside dozens of other languages that are also spoken.

Generally speaking, whenever people with dissimilar language repertoires meet, the choice of a common language - if such a choice is possible - depends on many variables, such as:

- language repertoires: which language(s) are understood/spoken by both speakers - and thus in principle available for the interaction?;

- habits: do the interlocutors know each other?, do they have an idea about the composition of each other's language repertoire?, have they already explicitly or implicitly agreed on a pattern of language choice?;

- balance of status: are the interlocutors on the same hierarchical level or does an unequal relationship (status, age, etc.) create a situation where one person can impose their language on the other?;

- situational factors: does the environment (e.g., the presence of other people) induce the choice or the avoidance of a language?, does the level of difficulty of a topic impede or permit choosing the language freely?;

- identity factors: are bi-/multilingual people willing to use any language they are able to speak or is it important for them to favour certain languages over others in order to display their linguistic identity?; and

10 This second module was repeated in another bilingual city, Fribourg (in German: Freiburg), where the majority language is French and the minority language is German. For the results as well as a comparison with Biel/Bienne, cf. Conrad and Elmiger (2010: 45-52). 
- subjective factors: are certain languages (permanently or momentarily) preferred or disliked by the interlocutors?

In Biel/Bienne, where at least two main languages are virtually always plausible, the following competing models are, at least in theory, likely to occur in the case of interactions between people that are new to each other:

a. the dominant language model: the majority language (i.e. German) is dominantly used/imposed as a common language of public interaction;

b. the "Swiss Model": ${ }^{11}$ in an interaction between two people speaking different languages, each person uses his/her preferred language and passively understand the other person (cf. Kolde 1981);

c. the "Biel/Bienne model": ${ }^{12}$ in an interaction between two people speaking different languages, one person (in general the one that starts the interaction) determines a common language, which is subsequently used by both participants.

The differences between the three models are numerous. Among other things, they concern the (un)equal status of the languages and the proficiency needed in order to ensure communication. In the dominant language model, only speakers of the minority language must be bilingual in order to be able to speak with members of the language majority. In the Swiss model, both interlocutors must have good receptive language skills in another language and in the Biel/Bienne model, both receptive and productive skills must be relatively high in order to ensure efficient communication.

On the basis of our research, the use of the dominant language model in the bilingual city of Biel/Bienne can clearly be excluded. In public spheres, one language does not completely dominate the other. ${ }^{13}$ In the anonymous recordings (module 2 in the project bil.bienne), most interactions followed the Biel/ Bienne model, i.e. the person that initiates an interaction determines the language of the exchange. This kind of mutual adaptation, which demands the highest form of language competence from both interlocutors of all three models, is a cue that lets us presume a high level of personal bilingualism (Conrad and Elmiger 2010: 36).

11 Cf. Kolde (1981), who calls it "Swiss" because it can be observed in Swiss Federal institutions (or meetings) involving mixed language groups.

12 Cf. Kolde (1981), for whom this model is typical for the Biel/Bienne context.

13 This is different in the bilingual city of Fribourg (Freiburg), where French is clearly the dominant language and the first choice for any interaction between strangers. German, the minority language, seems a plausible choice only between two German-speaking persons (Conrad and Elmiger, 2010: 45-52). 


\subsection{The linguistic social contract of Biel/Bienne}

It is impossible to predict the language(s) used in any context in which people with divergent language repertoires meet (for more details on language choice, cf. Elmiger and Matthey 2006; Conrad and Elmiger 2010). Instead, the findings of the bil.bienne project have given rise to a more general description of language choice for the specific local context in Biel/Bienne, which has been formulated as a kind of social contract (Conrad et al. 2002: 166), and serves as a theoretical description of the city's bilingualism: each linguistic group accepts and tolerates, individually as well as collectively, the other language group and claims the same for itself.

The findings of the bil.bienne-project show that this very general principle, which reflects the consensually functioning and socially supported bilingualism, seems to be implicitly accepted by a broad majority of people living in Biel/ Bienne. It doesn't imply - or impose - any fixed rules for specific situations, but it assures that neither group is continuously or exclusively discriminated against by members of the other group. By respecting each other, this social contract lays the ground for tolerant linguistic cohabitation in a bilingual setting (Conrad and Elmiger 2010: 44-45).

A participant of the first module (i.e. the long interviews with people living in Biel/Bienne) has put her interpretation of the rules for mutual cohabitation as follows:

\begin{tabular}{|c|c|c|}
\hline 1 & If & parce que (.) le bilinguisme justement c'est de DEUX côtés \\
\hline 3 & Mf & ouais \\
\hline 4 & If & je [trouve que] du moment où je me donne la peine \\
\hline 5 & Mf & [ouais ouais] \\
\hline 6 & If & de parler en allemand \\
\hline 7 & Mf & ouais \\
\hline 8 & If & $\begin{array}{l}\text { ehm on devrait se donner de la peine de me comprendre un } \\
\text { peu et d'essayer si on parle en français }{ }^{14}\end{array}$ \\
\hline
\end{tabular}

She stresses the necessity of mutual effort so that the minority group, by being able to understand and speak the majority language, is not uniquely responsible for making concessions. Bilingualism is collectively perceived as an accepted

14 Because bilingualism is from both sides./Yes./I think that/Yes yes./from the moment that I try to speak German/Yes/Well one should try to understand me somewhat and to try (to understand) if one speaks French. 
phenomenon and as a part of the social reality - as well as the concept behind of Biel/Bienne.

The Biel/Bienne social contract corroborates the officially equal status of both official languages, but it doesn't regulate language choice in individual events, where a common linguistic ground has to be found contextually. Flexibility (a key element in the social contract) is best achieved when a considerable number of people are not only able to adapt (i.e. by being able to speak both languages), but also willing to adjust to others - without feeling the obligation to do so constantly. Thus, both official languages are present in the public space, even though the choice of a common language in a given context can still be negotiated. This happens most often implicitly, without bringing up the question of language choice. However, when certain expectations (e.g. that everybody is fluent in both languages and willing to use them in any circumstance) are not fulfilled, that can lead to misunderstandings and resentments at the level of interpersonal communication. The cohabitation between the language groups in general, however, is perceived as nonconflicting.

\section{Reasons for a non-conflicting cohabitation}

Several reasons account for a globally non-conflicting cohabitation between the language groups in Biel/Bienne. Both main languages (German and French) enjoy a comparable - and very high - cultural status and both main language groups are comparable in terms of socioeconomic status, political and religious background. Overall, the composition of the main language groups in Biel/Bienne reflects the proportions of language groups in the whole country (cf. Section 2.1). ${ }^{15}$

Although the French group is clearly smaller than the German group, its weight (approximately one third) is still considerable; in recent years, the balance between the main language groups has remained relatively stable and there are no signs of geographic separation: throughout the city, there are no exclusively monolingual areas, which favours everyday contact and interactions between different language groups.

15 In Fribourg (German: Freiburg), the majority/minority proportions are inversed: German, the main language in Switzerland, is a minority at the regional and city level. This inversion of the minority/majority setting has often been pointed out to explain a less open and positive selfdefinition and self-promotion of Fribourg as a bilingual city. 
Bilingualism or other language-related topics are not isolated by specific political parties as an issue of conflict. Overall, all major political movements seem to favour bilingualism. More generally, the respect towards each other (as formulated in the Biel/Bienne social contract of language use) ensures that the majority group won't impose its language without sensitivity.

Hence, several conditions for a non-conflicting coexistence between several language groups are met and, mostly, cohabitation works rather well. In public surveys, a majority of the respondents express a positive attitude about the city's bilingualism. The results of the Bilingualism barometer (Longchamp et al. 2008a, 2008b) indicate, e.g., that most citizens consider that the main language groups live "next to each other" (50\%) or "with each other" (40\%); only 5\% consider that the live "against each other" (German: nebeneinander, miteinander, gegeneinander; French: en bonne entente, côte à côte, de manière conflictuelle).

\section{Zones of perceived conflict}

In the portrait of Biel/Bienne that we have provided until now, language conflict has been largely absent. Yet, the linguistic situation in this bilingual city is not free from conflict, despite the fact that it may appear on more subtle levels and may be carried out less violently than in other bilingual settings. While some issues may be inherent for any minority/majority context, others seem to derive from the dual status that the two main languages have in Biel/Bienne. A very particular role is played here by the official language promotion, which upholds two partly conflicting ideals. On the one hand, Biel/Bienne is promoted as a double monolingual city where everyone may live in their preferred language but must accept the presence of another language. On the other hand, it is promoted as a bilingual city with bilingual citizens whose language competences are in reality most often rather unbalanced.

\subsection{Reduced presence of the minority language}

Even though both main languages have in principle an equal status (see Section 3.3 on the linguistic social contract), it is clear that the sensitivity to language-related inequalities is much more developed by the members of the minority group. In the interviews that were conducted, the French-speakers showed a concern that the situation could deteriorate (and thus over time endanger the equality of the two official languages) and referred to the following points: 
- The pressure to be more proficient in the other language is greater for the minority group, especially when it comes to work places where language skills are important.

- The presence of the minority language (French) in public as well as in private media is often perceived as (too) marginal, compared to the majority language.

- The visibility of the minority language in the public linguistic landscape (Shohamy 2009) is often debated. While public signage (public information, road names, information on buses, etc.) is more or less systematically bilingual, there is no obligation for private stakeholders to use both official languages: private members of the civil society can only be encouraged to use both official languages in the public sphere (publicity, information about privately organised events or services).

- In public events where both languages are present, more attention is paid to people who express themselves in the majority language.

All these points can be summarised as the apprehension of the minority language to be gradually minoritised and superseded by a growing majority of German-speaking citizens, which would lead Biel/Bienne not only to be less francophone, but also less bilingual. Even though the statistical data do not uphold those fears (cf. Conrad and Elmiger 2010: 89), this perceived threat was referred to during the fieldwork by several individual respondents.

\subsection{Bilingualism and diglossia}

The French spoken in Biel/Bienne is not fundamentally different from varieties of French in other French-speaking regions of Switzerland. The same is true for German, but speaking German in Biel/Bienne - as in the whole Germanspeaking part of Switzerland - means that one has to be proficient both in Standard German and in dialect: Standard German is used in the media and for writing, dialect is used in oral communication and "conceptually oral" contexts (cf. Elmiger and Conrad 2005; Elmiger and Matthey 2006; Koch and Oesterreicher 2001). Local French-speaking people know about this diglossic situation - and as the data from the Bilingualism barometer indicate (see Section 2.1), many of them have good skills in both Standard German and its Swiss dialect.

French-speaking individuals from other regions may experience the diglossic situation in Biel/Bienne as a serious barrier and an additional obstacle for successful integration into a bilingual setting. That is especially true for people whose representation of "German" resembles that of "French", i.e. a more or 
less homogeneous language that shows little regional variation. In our data (module 1), a highly proficient bilingual speaker (L1: French, L2 German, having spent several years in Germany) reveals how traumatising it has been for her to discover that her oral proficiency (in Standard German) is not what counts in everyday use (where dialect is expected). Her excellent German even seems to prevent her from being considered a proficient bilingual person " $a$ la biennoise" (cf. Elmiger and Matthey 2006: 34-36, as well as Coupland 2010, about "authentic" or "legitimate" varieties of a language):

(2) If 14 das ist verrückt als WELsche wenn man hochdeutsch LERNT das lernt man in der schule (...) man sagt in der schweiz spricht man deutsch (--) dann lernt man DEUTSCH (...) dann sagt man nein das (tu?) was du gelernt hast ist kein deu=also ist nicht das was wir brauchen $^{16}$

\subsection{To be or not to be bilingual}

In a context in which individual bilingualism is a social reality and as such both favoured and expected, monolingual speakers can feel a certain pressure to become bilingual themselves. Being monolingual and thus not being able to be part of the bilingual speech community can therefore lead to a feeling of inferiority or embarrassment. In other words: it can be conflicting not to be bilingual. The following participant (module 1) considers her monolingualism as a sort of social stigma:

(3) If 07 aso es isch för mee $(s=\mathrm{f}=\mathrm{s})($.) in bieu nid chönne französisch rede isch piinlech ${ }^{17}$

Many people would welcome a more decisive promotion of personal bilingualism, above all through bilingual schooling, as the (traditionally separated) school system is seen as a factor that prevents further personal and collective bilingualism. ${ }^{18}$

16 'This is crazy, as a French speaker, if you learn Standard German, one learns it at school. They say that in Switzerland, people speak German, so you learn German. Then they tell you: No, what you have learnt is not Ger =, it's not what we need.'

17 'Well, for me - it is embarrassing not to be able to speak French, in Biel/Bienne.

18 In recent years, bilingual education (often as a reciprocal programme) has become increasingly popular, above all in higher secondary level; but also during compulsory schooling. 
Another conflicting issue that is related to the bilingual urban space - and the social contract that prevails over language relations - arises within interactions where one interlocutor expects the other interlocutor to be proficient in both languages, e.g. in citizen/administration or client/vendor situations. Here, citizens or clients clearly expect to be addressed in their preferred language. As a matter of fact, shops as well as other private stakeholders do not have to provide their services in both languages; nevertheless, the public has different expectations. When they are disappointed or frustrated - as in the following example - the postulate of equality for both official languages is undermined and bilingualism may be considered as endangered (cf. Heller 1982, for similar situations):

(4) If 26 le bilinguisme à bienne (.) c'est ça (.) c'est=euh (.) une petite fierté un petit drapeau qu'on agite mais c'est quelque chose qui se vit (.) pas vraiment (.) euh: (.) à la base je veux dire (.) vous pouvez (.) aller à la migros (.) à la migros de la place du marché (.) vous allez demander un croissant (.) TOUtes les semaines à la même dame à la même dame à la boulangerie (.) elle va chaque fois vous dire hä (-) voilà (.) je veux dire ÇA c'est le bilinguisme à bienne de $=\mathrm{de}=\mathrm{de}$ VIE au quotidien ${ }^{19}$

\subsection{Bilingualism as a threat to one's first language}

In both main language groups, the main language is solidly rooted and sustained by official institutions like education and administration as well as cultural and media offers. Therefore, the fear of losing one's first language is not common, although many people make extensive use of their bilingual language skills. Yet, several of the participants - especially members of the French-speaking community, have expressed an apprehension over gradually losing language fluency if they use the other language too often. Whereas no German-speaking interlocutor seems to have been preoccupied with the quality of his or her first language, some French-speaking informants consider bilingualism as a menace to the quality of the French language spoken in Biel/Bienne:

19 'Bilingualism in Biel/Bienne is like this; it is a little bit of pride, a small flag that one swings, but it is something that is not really lived. Well, basically I want to say: You can go to the Migros [a large Swiss retailing company], to the Migros at the market square, you go and ask for a croissant. Every week, the same lady, the same lady at the bakery: she'll say every time: "hä" [German; i.e. "I beg your pardon?"]. Well, I'd say that this is bilingualism in Biel/Bienne, in everyday life.' 
(5) If 30 la seule chose que:: (2 sec.) qui est moins bien (.) c'est qu'on perd beaucoup de vocabulaire (.) et que pour moi c'est bien de retourner en france régulièrement tous les mois

$\mathrm{Mm}$ ah

If 30 d'être avec des amis qui sont (-) purs francophones (...)

Mm vous trouvez que le français est: (.) appauvri en quelque sorte ici

If 30 ouais (.) je trouve oui

$\mathrm{Mm}$ pour quelles raisons

If 30 au niveau du vocabulaire au niveau: des constructions de phrases (-) du style

Mm et ça vous pensez que c'est dû:=euh (-) à quoi

If 30 ben je pense que c'est dû au bilinguisme ${ }^{20}$

A similar concern is raised by proficient bilingual speakers with an excellent command of so-called bilingual speech (i.e. the use of both languages in the same conversation, using different types of code-switching). Even though this may constitute a contextually efficient way of communication in a setting where bilingualism is considered rather positively, many individuals regard code mixing as an inherently flawed way of communication in comparison with an idealised 'pure' way of communication, where languages are used completely separately (cf. Heller 2007).

\section{Conclusion}

Overall, the city of Biel/Bienne is an example of urban multilingualism - paired with official bilingualism - where the preconditions for a non-conflicting cohabitation of different language groups are very favourable. The promotion of bilingualism as well as double monolingualism does not lead to major social or political tensions, but it is rather upheld as an important and unique feature of the city of Biel/Bienne. Each linguistic group accepts and tolerates the other language group and claims the same for itself. However, whereas Biel's official bilingualism is generally cherished, publicly supported and valued as a means to facilitate the

20 'The only thing that is less good is that one loses a lot of vocabulary and that for me it is good to return to France regularly every month./Ah./To be with friends that are pure Francophones./Do you think that the French language is somewhat impoverished here?/Yes, I do, yes./For what reasons?/On the level of vocabulary, sentence structures, style./And what do you think is the reason for this?/Well, I think this is due to bilingualism.' 
communication between people of different languages, our conversational data revealed that especially individual speakers at times perceive it to be problematic as well. Some experience the fact that they (as well as some of their interlocutors) are not able to speak the other's language in an officially bilingual city as a shortcoming or at least a source of irritation. That especially counts for the members of the Francophone minority who have the impression that the pressure on them to be bilingual is higher than in the case of the members of the Germanspeaking majority. Next to being envied by monolingual speakers, bilingualism is also seen as a particular challenge by some members of the Francophone minority who do master the German language. The reason for this is that the mastery of German not only implies the mastery of a standard variety of German but also the mastery of the local Swiss dialect that is a key to successful integration. If one adds the fact that some members of the Francophone minority have the impression that the dominant varieties of German pose a threat to the purity of French, then it becomes clear that the - in general widely appreciated - bilingualism as it is promoted in Biel feeds the perception that it damages the individual languages (i.e., most notably French as a minority language). The fact that there is clearly a majority language - and that the minority group latently fears dwindling significance - seems understandable, as well as the fact that the German-speaking majority group as a whole may be less aware of the difficulties and discrimination that the French-speaking minority group is faced with. Even though the findings of the bil.bienne project show that members of the minority group sometimes tend to simplify or idealise the situation of the majority group, it is clear that the city's simultaneous promotion of bilingualism and double monolingualism succeeds in neutralizing potential language conflicts at the group level, yet due to the different weight of French and German in society also gives rise to certain expectations and/ or irritations at the individual level that may lead to language conflict.

Acknowledgment: We would like to thank Sarah-Jane Conrad for her valuable comments on a first draft of this text and Holli Schauber for her corrections and comments.

\section{Appendix: Transcription conventions}

In the transcriptions, we use a simplified version of the GAT-protocol (Selting et al. 1998):

[]

(.) (-) (--) (---)

overlapping speech

short pauses

uninterrupted speech 


$\begin{array}{ll}(\ldots) & \text { omission } \\ \ll \gg> & \text { indications about diction etc. } \\ ::::: & \text { elongated speech } \\ (1 \mathrm{sec} .) & \text { longer pauses (in seconds) } \\ (\mathrm{xxx}) & \text { incomprehensible segment } \\ () & \text { supposed segment } \\ (()) & \text { paralinguistic and non-linguistic behaviour } \\ \text { CAPITAL LETTERS } & \text { stressed pronunciation }\end{array}$

Speakers: If, Im (female, male informant); Mf, Mm (female, male project collaborator).

\section{References}

Ammon, Ulrich. 2006. Language conflicts in the European Union. On finding a politically acceptable and practicable solution for EU institutions that satisfies diverging interests. International Journal of Applied Linguistics 16(3). 319-338.

Boix-Fuster, Emili \& Jaume Farràs. 2013. Is Catalan a medium-sized language community too? In F. XavierVila (ed.), Survival and development of language communities. Prospects and challenges, 157-178. Bristol: Multilingual Matters.

Calvet, Louis-Jean. 1987. La guerre des langues. Paris: Payot.

Conrad, Sarah Jane, Alexis Matthey \& Marinette Matthey. 2002. Bilinguisme institutionnel et contrat social: le cas de Biel-Bienne (Suisse). Marges Linguistiques 3. 159-178. http:// www.revue-texto.net/Parutions/Marges/00_ml052002.pdf (accessed 7 July 2015)

Conrad, Sarah-Jane \& Daniel Elmiger (eds.). 2005. Villes bilingues - Zweisprachige Städte Bilingual Cities. Akten des Kolloquiums in Biel/Bienne, 19-20. März 2004 [Special issue]. Bulletin VALS-ASLA 82. Neuchâtel: Centre de Linguistique Appliquée.

Conrad, Sarah-Jane \& Daniel Elmiger (eds.). 2010. Leben und Reden in Biel/Bienne. Kommunikation in einer zweisprachigen Stadt/Vivre et communiquer dans une ville bilingue. Une expérience biennoise (Mannheimer Beiträge zur Sprach- und Literaturwissenschaft 77). Tübingen: Narr.

Coupland, Nikolas. 2010. The authentic speaker and the speech community. In Carmen Llamas \& Dominic Watts (eds.), Language and Identities, 99-112. Edinburgh: Edinburgh University Press.

Darquennes, Jeroen, Peter Hans Nelde \& Peter J. Weber (eds.). 2004. The future has already begun. Recent approaches in conflict linguistics. Forschungsansätze der Konfliktlinguistik. Tendances de la linguistique de conflit (Plurilingua XXV). St. Augustin: Asgard.

Darquennes, Jeroen. 2010. Language contact and language conflict in autochthonous language minority settings in the EU. Multilingua 29(3/4). 337-351.

Darquennes, Jeroen. 2013. Language policy and planning in indigenous language minority settings in the EU. Revue Française de Linguistique Appliquée XVIII(2). 103-119.

Elmiger, Daniel. 2005. L'orientation de Bienne comme ville bilingue: entre protection du monolinguisme et promotion du bilinguisme. Bulletin VALS-ASLA 82. 17-29.

Elmiger, Daniel \& Sarah-Jane Conrad. 2005. Un bilinguisme peut en cacher un autre: bilinguisme et diglossie à Biel/Bienne. Bulletin VALS-ASLA 82. 31-42.

Elmiger, Daniel \& Sarah-Jane Conrad (eds.). 2006. Le projet bil.bienne - bilinguisme à bienne * kommunikation in biel. [Special issue]. Travaux Neuchâtelois de Linguistique (TRANEL) 43. 
Elmiger, Daniel \& Marinette Matthey. 2006. La diglossie vu du "dedans" et du "dehors": l'exemple de Bienne et d'Evolène. Travaux Neuchâtelois de Linguistique (TRANEL) 43. 23-47.

Extra, Guus \& Kutlay Yağmur (ed.). 2004. Urban multilingualism in Europe. Immigrant minority languages at home and school. Clevedon, $\mathrm{OH}$ : Multilingual Matters.

Flubacher, Mi-Cha \& Alexandre Duchêne. 2012. Eine Stadt der Kommunikation: urbane Mehrsprachigkeit als Wirtschaftsstrategie? Bulletin Suisse de Linguistique Appliquée (Bulletin VALS/ASLA) 95. 123-142.

Haarmann, Harald. 1990. Elements of a theory of language conflict. In Peter H. Nelde (ed.), Language attitudes and language conflict (Plurilingua IX), 1-15. Bonn: Dümmler.

Heller, Monica. 1982. “Bonjour, hello?”: Negotiations of language choice in Montréal. In John J. Gumperz (ed.), Language and social identity, 108-118. Cambridge: Cambridge University Press.

Heller, Monica. 2007. Bilingualism as ideology and practice. In Monica Heller (ed.), Bilingualism: A social approach, 1-22. London: Palgrave Macmillan.

Hitchings, Henry. 2011. The language wars. New York: Farrar, Straus \& Giroux.

Koch, Peter \& Wulf Oesterreicher. 2001. Gesprochene Sprache und geschriebene Sprache/ Langage parlé et langage écrit. In Günther Holtus, Michael Metzeltin \& Christian Schmitt (eds.), Lexikon der Romanistischen Linguistik I/2, 584-628. Tübingen: Niemeyer.

Kolde, Gottfried. 1981. Sprachkontakte in gemischtsprachigen Städten. Vergleichende Untersuchungen über Voraussetzungen und Formen sprachlicher Interaktion verschiedensprachiger Jugendlicher in den Schweizer Städten Biel/Bienne und Fribourg/Freiburg i. Ue. (Zeitschrift für Dialektologie und Linguistik, Beihefte 37). Wiesbaden: Steiner.

Longchamp, Claude, Matthias Bucher, Stephan Tschöpe \& Silvia Ratelband-Pally. 2008a. Anstrengungen zur Zweisprachigkeit wirken sich positiv aus. Schlussbericht zum „Zweisprachigkeitsbarometer der Stadt Biel/Bienne 2008“. Bern: Gfs.bern.

Longchamp, Claude, Matthias Bucher, Stephan Tschöpe \& Silvia Ratelband-Pally. 2008b. Les efforts en matière de bilinguisme sont payants. Rapport final Baromètre du bilinguisme de la ville de Biel/Bienne 2008. Berne: Gfs.bern.

Lüdi, Georges \& Iwar Werlen. 2005. Sprachenlandschaft in der Schweiz/Le paysage linguistique en Suisse. Neuchâtel: Bundesamt für Statistik/Office Fédéral de la Statistique.

Mac Giolla Chríost, Diarmait. 2003. Language, identity and conflict. London: Routledge.

Müller, Christoph. 1987. Zweisprachigkeit in Bienne-Biel. Schlussbericht im Rahmen des Forschungsstudiums am Soziologischen Institut der Universität Zürich. Zürich: Universität Zürich.

Nelde, Peter Hans. 1987. Language contact means language conflict. Journal of Multilingual and Multicultural Development 8(1/2). 33-42.

Nelde, Peter Hans. 1998. Language conflict. In Florian Coulmas (ed.), The handbook of sociolinguistics, 285-300. Malden et al.: Blackwell.

Nelde, Peter Hans. 2006. La linguistique de contact, la recherche sur le conflit linguistique et l'aménagement linguistique au XXe siècle. In Sylvain Auroux et al. (eds.), History of the language sciences, 2413-2429. Berlin \& New York: de Gruyter.

Oksaar, Els. 1984. Spracherwerb - Sprachkontakt - Sprachkonflikt. Berlin \& New York: Walter de Gruyter.

Pavlenko, Aneta. 2009. Language conflict in post-Soviet linguistic landscapes. Journal of Slavic Linguistics 17(1/2). 247-274.

Rouchdy, Aleya (ed.). 2003. Language contact and language conflict in Arabic: Variations on a sociolinguistic theme. London: Routledge-Curzon. 
Selting, Margret, Peter Auer, Birgit Barden, Jörg Bergmann, Elizabeth Couper-Kuhlen, Susanne Günther, Christoph Meier, Uta Quasthoff, Peter Schlobinski \& Susanne Uhmann. 1998. Gesprächsanalytisches Transkriptionssystem (GAT). Linguistische Berichte 173. 91-122.

Shohamy, Elana \& Durk Gorter. 2009. Linguistic landscape. Expanding the scenery. New York \& London: Routledge.

Stadt Biel/Ville de Bienne. 2012. Statistisches Fact Sheet/Données statistiques. http://www.biel-bienne.ch/files/pdf4/pra_sm_fact_sheet_01.04.2014_d_f.pdf (accessed 18 June 2014).

Trudgill, Peter. 1997. Norwegian as a normal language. In Unn Røyneland (ed.), Language contact and language conflict, 151-158. Volda: Volda College.

Werlen, Iwar (ed.). 2000. Der zweisprachige Kanton Bern. Bern/Stuttgart: Haupt. 